\title{
Explaining 'Inertia' in R\&D internationalisation: Norwegian firms and the role of home country-effects
}

\author{
Rajneesh Narula* \\ Professorial Fellow \\ University of Oslo, MERIT and the STEP group
}

14 July 2000 (AV)

\begin{abstract}
We ask why firms from certain countries show a higher propensity to centralise their R\&D activities at home than firms from other countries, using the example of Norway. We highlight that it is the interplay between the industrial structure and political and economic orientation of the home economy that plays an important role in how firms engage in both home and overseas activities, including R\&D. In general, national systems of innovation (NSI) and industrial and technological specialisation of countries changes only very gradually, and - especially in newer, rapidly evolving sectors - much more slowly than the technological needs of firms. Thus, firms must either import and acquire the technology they need from abroad, or venture abroad and seek to internalise aspects of other countries' NSI. In the case of Norway, two groups of firms exist. The first group are large firms in traditional sectors, that are highly embedded, and around whom the Norwegian NSI has been built, and which have a low level of R\&D internationalisation. The second group of firms are SMEs in science based sectors who are (slowly) expanding R\&D abroad to seek competences in technologies not available domestically. The low $R \& D$ internationalisation of both groups reflects their embeddedness in the domestic NSI, which has acted as a powerful centripetal force, creating a technological and organisational inertia.
\end{abstract}

Keywords: R\&D, internationalisation, inertia, technology, NSI, coordination, SMEs, lock-in, path dependence, Norway, small countries, innovation systems, industrial policy, outsourcing.

Corresponding address:

Dr. R. Narula

Centre for Technology, Innovation and Culture (TIK Centre)

University of Oslo

PO Box 1108 Blindern

N-0317 Oslo, Norway

Phone: +4722958830

Fax: +4722958845

e-mail: rajneesh.narula@tik.uio.no

* I am obliged to Marina Papanastassiou and Bob Pearce for help in designing the original questionnaire. Research funding by the Norwegian Research Council is acknowledged. The first draft of this paper was presented at the Oslo conference of the MESIAS/STRATA network meeting, June 2000. Comments by Rene Belderbos, Keith Smith, Olav Wicken, Henrik Brastaad, Christian Bellak, and Gabriel Benito have helped in finalising this paper. 


\section{Explaining 'Inertia' in R\&D internationalisation: Norwegian firms and the role of home country-effects}

\section{Introduction}

This paper enquires why firms of different nationalities exhibit different propensities to undertake international $R \& D$ activities. We focus on reconciling the heterogeneity and idiosyncratic behaviour of individual firms in their location of $R \& D$, with the apparent similarity in $R \& D$ internationalisation patterns by firms of a given nationality. The more aggregate evidence on $R \& D$ internationalisation points to similarities in internationalisation between firms from similarly endowed countries. Our discussion does not preclude the role of industry-specific effects, but argues that the three levels of analysis - firm-specific, industryspecific and country-specific - are indeed complementary and indivisible.

The starting point of our analysis is the heterogeneity in the propensity of small open economies (SOEs) to undertake overseas asset-developing activities. Some have generalised that SOEs -which are both supply and demand constrained- locate a larger proportion of their value adding activities overseas, and a considerable amount of their innovative capacity, relative to larger, better endowed economies. However, the variation between SOEs is considerable: firms from countries such as Belgium, Sweden, the Netherlands demonstrate such tendencies, while firms from countries such as Norway, Austria and Finland are less inclined to do so. Indeed, supply and demand constraints due to size do not seem to be the primary explanation, with firms from larger countries such as Italy and Japan exhibiting a similar reluctance to internationalise their innovative activities.

This paper seeks to examine the reasons underlying this discrepancy, and in particular to understand the role of home-country effects on firms' reluctance to internationalise their $R \& D$. We take the example of Norway, using data based on interviews with the major R\&D performers in Norwegian industry.

There are undoubtedly several complex forces at play which determine the extent and location of innovation from the firms and strategic perspective, and which have been the object of numerous other studies examining the centripetal and centrifugal forces underlying the innovative activities of firms (see e.g., Granstand, Hakanson and Sjolander 1994, Niosi 1999, Granstand 1998). We accept that 'inertia' in R\&D internationalisation certainly reflects all these issues. Our contribution in this article is to focus and expand on the complex interplay between several country-specific issues that determine internationalisation - or in 
this case, non-internationalisation - of R\&D by firms. In particular, we focus on the extent to which firms are embedded and interdependent on the external (but national) actors that comprise the national innovation systems and determine the industrial specialisation of firms, their competitiveness and the extent to which they are embedded. While understanding the centripetal nature of supply-side issues is not novel, we take a more holistic approach, examining both exogenous (factor-endowments based aspects) and endogenous (government institutions and regulatory aspects) issues. While the nature of comparative advantages act as an exogenous factor, a priori creating bounds on what is possible, the industrial structure in 'reluctant' internationalising economies also tends to exhibit the effects of inward-looking economic policy orientation and a certain level of techno-nationalism, and acts (in certain instances) to constrict both inward foreign direct investment (FDI), and to an extent at least impedes outward activity. In other words, firms - both small and large -may be 'locked-in' to the local innovation systems, since the level of interaction and the extent of interdependence is difficult to duplicate elsewhere. In addition, the specialisation of the innovation systems changes only very gradually, and often firms have to respond more rapidly to the changing global competitive environment than the domestic milieu allows. Thus, firms are pushed reluctantly- to seek complementary assets which the home location cannot provide as efficiently.

\section{Country effects and internationalisation}

There is considerable evidence - particularly on a macro- and meso-economic level - that firms from SOEs tend to demonstrate a higher propensity to internationalise their value adding activities than firms from larger economies (see e.g., Freeman and Lundvall 1988). The reasons for this are uncontroversial. From a demand perspective, the relatively limited domestic market size means that if such firms are to achieve economies of scale in production, they must seek additional markets to that of their home location in order to increase their de facto market size ${ }^{1}$ (Walsh 1988, Narula 1996, Bellak and Cantwell 1997). From a supply perspective, the smallness of their economies means that they have limited resources, in terms of capital (both financial and human) as well as in terms of natural and created assets, such that firms from these countries tend to be specialised in a few sectors. The industrial structure of SOEs tends to demonstrate a 'niche' character, with a high level of specialisation in few areas, where firms act as specialist suppliers, and thereby show a low

\footnotetext{
${ }^{1}$ The issue here is to seek access to markets, which may firms may do either through exports or FDI.
} 
level of product diversification. Bellak and Cantwell (1997) posit that these sectors will tend to be those in which they can achieve price-setter positions.

For similar reasons, industrial policy in these countries tends to support this specialisation, because governments have a choice between spreading their limited resources thinly across many industries, or concentrating them in a few targeted industries. Thus, if firms from SOEs require inputs not available locally and they must therefore seek these in overseas locations. It is a well-known observation that this specialisation is reflected in the structure and distribution of their domestic industry, as well as their trade and FDI (see e.g., Cantwell 1989, Narula 1996). In the case of international production, the tendency to internationalise (in an absolute sense and in terms of foreign production as a percentage of total production), is less clear cut. Belgium, Netherlands and Sweden, for instance, demonstrate a high level of internationalisation of value-adding activities, while countries such as Norway and Austria (and until recently, Finland) have shown a dogged preference for concentrating their value-adding activities at home, preferring to focus on exports and licensing. Such heterogeneity in internationalisation tends also extends to larger economies, suggesting that in fact, smallness per se may not be the primary consideration. Indeed, Dunning and Narula (1996) argue that the propensity to engage in international production depends on the balance between the home country's natural and created assets, which in turn, is a function of its resource structure, its market size, and its policy orientation.

The basic point that we wish to emphasise here is relatively uncontroversial: there exists a fundamental interdependence between the home country national systems and the technological competitiveness of their firms. The national systems of innovation (NSI) concept suggests that there exist certain structural influences (scientific, political, and socioeconomic) within any nation state that help to define that pattern, nature and extent of knowledge accumulation within a given industry, which also defines the extent and nature of industrial innovation within its borders. At a more general level, there are national systems that support business activities, much like the NSI concept.

The use of the word 'system' does not necessarily mean that the various influences that underpin the generation of industrial innovation are systematically organised (Nelson and Rosenberg 1993). Far from it. Indeed, it is probably more accurate to say that the NSI in most cases represents the serendipitous intertwining of institutions and economic actors within industry which defined the stock of knowledge in a given location ${ }^{2}$. Changes in one institution

\footnotetext{
${ }^{2}$ This is one of the primary arguments for the 'triple helix' approach proposed by Etzkowitz and Leydesdorff (2000).
} 
due to, say, a change in the educational priorities of a new government, are likely to affect other institutions, and eventually, the nature of innovatory activities of firms within given industries, thereby influencing the process and extent of technological learning in future periods.

Technological accumulation is incremental, and highly path-dependent, whether one views it from a firm, industry or national perspective. Thus, technological specialisation patterns are distinct across countries, despite the economic and technological convergence associated with economic globalisation (Archibugi and Pianta 1992, Narula 1996). Other studies have shown that these patterns of technological specialisation are fairly stable over long periods (see Cantwell 1989, Zander 1995) and change only very gradually. The kinds of technologies across countries have shown to have converged because of, inter alia, increasing cross-border competition and the increasing interdependence of economic actors in different locations. Cantwell and Sanna-Randaccio (1990) have shown, for instance, that firms seek to emulate the technological advantages of leading competitors in the same industry, regardless of their national location. Similarly, Narula and Hagedoorn (1999) have shown that firms seek to engage in $R \& D$ alliances with technological leaders in the same industry, irrespective of their national origins.

Note that the increasing similarity of technological assets across countries has not made their technological advantages identical (Narula 1996). In part, this is because a majority of the activities of firms- and in particular their innovative activities- tend to be concentrated in their home location. Since the NSI of the home country is idiosyncratic, pathdependent and stable, the specialisation of their firm's activities are also broadly speaking specialised in these same sectors, despite their increasing international involvement through overseas value adding activities (Narula 1996). Indeed, this in part reflects the fact that the R\&D activities - particularly those directed towards more fundamental research activities tend to be conducted closer to headquarters.

\section{Explaining inertia and heterogeneity in R\&D Internationalisation}

Studies on the internationalisation of $R \& D$ have linked the theories that underlay the location of international production to explain the location of the R\&D activities of firms. R\&D can be said to internationalise for broadly the same motives as traditional elements of the value added chain, although not at the same rate, nor to the same extent. Two primary types of R\&D activity have been identified within this approach.

First, firms internationalise their $R \& D$ because of the need to improve the way in which existing assets are utilised. That is, firms may seek to promote the use of their 
technological assets in conjunction with, or in response to, specific locational conditions in a foreign locale. This has been dubbed as asset-exploiting R\&D (Dunning and Narula 1995) or home-base exploiting (HBE) activity (Kuemmerle 1996). Locational conditions may require some level of modification to the product or processes in order to make them more appropriate to local conditions, or in some cases, to create peripheral products. Such R\&D is primarily production-supportive, and (within the classification developed by Hood and Young 1982) leads to the establishment of support laboratories (SL), or locally integrated laboratories (LIL). In such activities, the technological advantages of the firm primarily reflect those of the home country.

Unsurprisingly, the heterogeneous internationalisation behaviour observed with regards international production extends to $R \& D$ activities. This is because a large percentage of the foreign-located $R \& D$ activities of firms tends to be production-supportive (i.e., HBE), the demand-side considerations are significant. Countries with a higher involvement in foreign production also demonstrate a higher proclivity towards foreign-located $R \& D$. The level of foreign $R \& D$ in any given host location is however, also dependent on the kinds of value adding activity undertaken there. Trade supportive activities or minor assembly-type operations are less likely to result in much demand driven $R \& D$ activity. Where the production activities are more intensive, such as with efficiency-seeking FDI, will have more. In general, the more embedded the foreign subsidiary, and the greater the intensity of the value-adding activity, the greater the amount of $R \& D$ activity. Such activities lead to an duplication of its home base activities, since the host location is acting as a substitute for activities it may have wished, ceteris paribus, to undertake at home (Zander 1999), but find that it can undertake these more efficiently elsewhere.

The second broad classification is that of strategic asset-seeking activity (Dunning and Narula 1995) or home-base augmenting (HBA) activity (Kuemmerle 1996). In such kinds of investments, firms aim to improve their existing assets, or to acquire (and internalise) or create completely new technological assets through foreign-located $R \& D$ facilities. The assumption in such cases is that the foreign location provides access to location advantages which are not as easily available in the home base. In many cases the location advantages sought are associated with the presence of other firms. The investing firm may seek to acquire access to the ownership advantages of other firms, either through spillovers (in which case the firm seeks benefits that derive from economies of agglomeration), by direct acquisition (through M\&A), or through R\&D alliances. In the Hood and Young classification, these R\&D facilities might represent internationally integrated laboratories (IIL). 
HBE activity, broadly speaking, represents a duplication of R\&D work undertaken at home, while HBA activity represents a diversification into new scientific areas. Zander (1999), in a study of Swedish MNEs, further expands this taxonomy of international innovation networks. He proposes that although it is possible to argue, as others have done (e.g., Patel and Vega 1999, Dunning and Narula 1995), that international duplication of R\&D activities is in fact an indication of technological strength of the home base, whereas when firms diversify, it reflects a weakness in the home base, but a strength in the host location. But Zander goes further, explaining that a dichotomous view is a simplification of a complex system, given that firms are different and are often engaged in several kinds of activity simultaneously. Indeed, his results suggest that there exists a continuum in terms of diversification and duplication, each not being independent of the other. That is to say, firms may seek to both duplicate and diversify, depending on the nature, diversity and intensity of their activities.

Supply issues are crucial in explaining the heterogeneity of firms in their extent of R\&D activity. It is important to note that not all supply-side issues result in HBA R\&D activity. First, firms may seek assets that are not associated with innovatory activities, as is the case where resource-seeking investments are undertaken. For instance, the home country may have a comparative disadvantage in unskilled labour, or a natural resource that represents a crucial input to its value adding process. So while such investment is essentially home-base augmenting, it does not necessarily involve R\&D. This is an important form of FDI for MNEs from all countries regardless of size. It is when the firm seeks complementary assets in nongeneric, knowledge-intensive, and location bound assets which it cannot have access (or as cheaply) to in its home base, that firms engage in HBA activities through FDI. The growth of HBE activity by MNEs since the mid 1980s or so has been noted by a variety of authors (see e.g., Florida 1997, Kuemmerle 1996). It is important to note that there is considerable variety in the kinds of activity that can be so defined. First, firms may seek to establish 'listening posts' which essentially monitor the activities of other firms and institutions in a particular environment. Such listening posts have a low R\&D intensity, as their role is primarily that of technological reconnaissance, and not $\mathrm{R} \& \mathrm{D}$ per se. Such activities seek indirect spillovers, but do so deliberately and tend to be small in size. At the other extreme, firms may engage in $\mathrm{R} \& \mathrm{D}$ in a foreign location to avail themselves of complementary assets that are location specific (and include those that are firm-specific or institution-specific, which the laboratory in question seeks to use through collaboration). That is, such technological activities aim explicitly to internalise several aspects of the NSI of the host location, by seeking direct 
spillovers, in addition to indirect spillovers. Such facilities may be small or large, depending largely on the resources and the objectives of the parent firm.

Despite the problem created by the aggregation of data, the evidence unambiguously suggests that firms from certain countries show a markedly similar tendency towards centralising their R\&D activities, while others show a strong bias towards internationalisation. For instance, Japan has long represented the exception amongst large economies, with its MNEs exhibiting a low level of R\&D internationalisation (e.g., Pearce and Singh 1992, Patel and Pavitt 1998). Despite the considerable level of internationalisation of the sales and production of its firms, its level of international $R \& D$ activity has remained at a modest level. Two complementary explanations exist (Belderbos 1999, 2000). First, that this is simply a corollary of 'latecomer' status of Japanese firms in internationalisation generally. That is, because Japanese firms have internationalised their production activities only relatively recently, and it is reasonable to expect a lag before they engage in substantial levels of international R\&D activity. Second, that this reflects unique characteristics of Japanese management, and of their linkages with the domestic innovation system. At the risk of oversimplifying, the latter argument is that firms that dominate Japanese international activities are to a great extent large MNEs which are 'core' members of the Keiretsu. These firms are deeply embedded in the Japanese science and technology base, and this century-long interdependence ${ }^{3}$ between these firms and the innovation systems in Japan has created an inertia amongst these firms, and a consequent bias towards home-base activities, and -until quite recently - a preference to augment technological assets through external or quasiexternal means ${ }^{4}$. What we are trying to suggest here is that this dual argument may be generalised to a larger group of countries. Similar low levels of R\&D internationalisation has also been noted for firms from other countries, including the Austria, New Zealand, Norway and Italy ${ }^{5}$. Although there are industry-specific tendencies resultant from their industrial structure (discussed later), these countries also have innovation systems that are 'tight' in the sense they have in the past been closed (or at least had high barriers of entry) to new (but particularly foreign) entrants, and generally speaking display a certain level of 'technonationalism', often demonstrated through their low levels of penetration of inward FDI. Economic policy may, in some cases, have been explicit through the use of a strong import-

\footnotetext{
${ }^{3}$ Although the keiretsu are a post war phenomenon, they have broadly the same group membership as the prewar conglomerates called the zaibatsu.

${ }^{4}$ See Dunning and Narula (1994), Pearce and Papanastassiou (1996), Belderbos (1999, 2000)

5 As Patel and Pavitt (1998) show, high levels of international production do not automatically translate to high levels of international R\&D.
} 
substituting stance, and a strong centrally-orchestrated technology policy. Indeed, such behaviour has been quite common amongst a number of SOEs (Davenport and Bibby 1999), but is by no means limited to them. Such habits die hard, and the close-knit relationships developed through such policies remain strong, long after the policies that created them have been abandoned. Despite this, the evidence that innovation is becoming increasingly internationalised is quite strong (see e.g., Archibugi and Iammarino 2000). Some of this growth has occurred through non-conventional, quasi-internalised modes, such as strategic technology partnering (see e.g., Narula and Hagedoorn 1999). Indeed, both internal and external R\&D activities show an increasing overlap. That is, firms establish R\&D facilities overseas partly in order to develop and maintain external networks of relationships with local counterparts (Zanfei 2000).

But the need to create durable linkages with the innovation systems of a host location - especially where the firm is seeking mainly to duplicate its technological profile overseas is tempered by a high level of integration with the innovation system in the home location. Such linkages are both formal and informal, and will probably have taken years - if not decades - to create and sustain. Frequently, the most significant issues are the 'know-who'. Government funding institutions, suppliers, university professors, private research teams, informal networks of like-minded researchers take considerable effort to create, and once developed, have a low marginal cost of maintaining. Even where the host location is potentially superior to the home location - and where previous experience exists in terms of other value adding activities-the high costs of becoming familiar with, and integrating into a new location may be prohibitive. Keep in mind that firms are constrained by resource limitations, and that some minimum threshold size of R\&D activities exist in every distinct location. As such, to maintain more than one facility with a threshold level of researchers must mean that the new (host) location must offer significantly superior spillover opportunities, or provide access to complementary resources that are simply not available anywhere else, and which cannot be acquired by less risky means more efficiently. Where firms simply seek to duplicate their home activities abroad, the decentralisation imperative is still less powerful. This may be achieved more simply by strategic alliances, in addition to which, of course, improvements in information and communication technologies (ICTs) have further reduced the need for physical proximity. This may also explain in part the growing use of $M \& A$ activity with regards to $R \& D$. An acquired laboratory short-circuits the time taken to develop such linkages vis-à-vis a greenfield laboratory, as they come with readymade networks and linkages (Narula 1999a). However, acquired laboratories bring with them 
the difficulty of integrating them efficiently into the internal network of the firm, such that their efficiency may be limited, at least initially (Belderbos 1999).

It seems clear, nonetheless, that allowing for differences in the motivation to conduct overseas R\&D (which may themselves derive from simple firm- and industry-specific differences), geographical proximity to host locations is important in determining the location of $R \& D$, in both the case of supply and demand-driven $R \& D$ activity. However, Blanc and Sierra (1999) point out that that internal proximity between overseas R\&D and the rest of the $\mathrm{MNE}$ is an equally important issue. A dispersion of $\mathrm{R} \& \mathrm{D}$ activities across the globe also requires extensive coordination between them - and particularly with headquarters- if they are to function in an efficient manner with regards to the collection and dissemination of information. This acts as a centripetal force on $R \& D$, and accounts for a tendency of firms to locate $R \& D$ (or at least the most strategically significant elements) closer to headquarters.

Such growing complex linkages, both of networks internal to the firm, and those between external networks and internal networks, require complex coordination if they are to provide optimal benefits (see Zanfei 2000 for a discussion). Such networks are not only difficult to manage, but also require considerable resources (both managerial and financial). It is no surprise, therefore, that external technology development is primarily the domain of larger firms with greater resources, and more experience in trans-national activity (Hagedoorn and Schakenraad 1994, Castellani and Zanfei 1998). SMEs are generally not in a position to undertake such activity. While it is true that ICTs have improved coordination, the importance of 'being there' and having direct contact remains especially important in $R \& D$, where much of the knowledge is not only tacit and largely uncodifiable, but embodied in people.

Thus it seems reasonable to expect that large firms to undertake a higher level of R\&D overseas, although in proportion this may be the same as smaller firms. Indeed, this is the conclusion made by Patel and Vega (1999), among others. Small firms are constrained by their limited resources - the expansion of R\&D activities- both at home and in overseas locations requires considerable resources both in terms of capital investment, and managerial resources which these firms simply do not have. Ceteris paribus, large firms have more money and resources to use on overseas activity. On the other hand, large firms are also more likely to have more linkages with the domestic science base, and tend to have a well developed network of supplier firms at home. Small firms are generally in the role of supplier firm, and as such form part of the network of some larger firm, and are thus also bound to their home location (or the location of their main customers). Internationalisation of supplier firms often occurs in tandem with the internationalisation of their primary customer, 
especially where the customer is large and dominant in terms of their market, as has been observed with regards Japanese auto manufacturers and their network of supplier firms as the auto manufacturers have relocated production to the US and Europe (Florida 1997). However, even when such strong customer - supplier links are not the case, small firms are constrained by limited resources. R\&D is a costly and slow affair, and the long-term horizon that such investments need makes overseas $\mathrm{R} \& \mathrm{D}$ facilities an expensive and risky option which is hard to justify. Indeed, Belderbos (2000) find that there is a non-linear relationship between firm size and overseas R\&D, with medium-sized Japanese firms showing a higher propensity (in relative terms) to internationalise $R \& D$ than small or large sized firms.

There are also considerable industry-specific differences which encourage or discourage centralisation ${ }^{6}$. As Teece (1986) has argued, the maturity of the technology, and its characteristics, determines the extent to which the innovation process can be internalised. Obviously, every technological trajectory of each individual firm is unique, since the innovation process is path-dependent on previous innovation. In other words, there are cognitive limits on what firms can and cannot do (Pavitt 1998). Most mature technologies evolve slowly and demonstrate minor but consistent innovations over time, and can be regarded as post-paradigmatic. The technology is to a great extent codifiable, widely disseminated, and the property rights well-defined. Innovation is rarely patentable in these technologies, where applications development account for most innovatory activity. Competition shifts towards price, economies of scale, and downstream activities in order to add value, as the original product is priced as a commodity. These sectors tend to have a low R\&D intensity. These sectors are generally what Lall (1979) refers to as process industries do not require outputs to be tailored to customers to the same extent, or as quickly. This means that constant and close interaction between customers is not an important determinant of R\&D. Profits of firms are highly dependent on the costs of inputs, and proximity to the source of these inputs is often more significant than that of customers. On the other extreme, rapidity of technological change in 'newer' technologies, or what Lall (1979) refers to as engineering industries, require a closer interaction between production and $R \& D$. Technologies has a higher tacit, uncodifiable element, and this requires a closer coordination between users and producers of innovation.

The growing need for firms - particularly in technology intensive sectors - to have multiple technological competences is by now also axiomatic. Several contributions, notably

\footnotetext{
${ }^{6}$ It should also be noted that firms in more mature sectors are more likely to be large, because concentration tends to be higher in such sectors than more rapidly evolving sectors.
} 
by Granstand and associates (see e.g., Granstand 1998, Granstand, Patel and Pavitt 1997) have noted the growing technological diversification of companies, and more recently, that this is associated with a reduction in product diversification over time. Even where products are mono-technology-based, the processes used to manufacture them often utilise several technologies. Furthermore, within a given technology, there are several technological paradigms at play, as firms base products on the current dominant design, yet develop nascent technologies with the long-term intention of replacing the current technology with a new dominant design. In sectors where a dominant paradigm is not as yet defined, and where several disparate technologies are required, interaction with customers and firms with complementary technologies, either at home or abroad is greater.

What we are trying to highlight here is that the complex - and sometimes contrary forces influences the tendency of firms to internationalise, and these occur at both the micro and macro levels. On the one hand, there are firm- and technology-specific forces. In particular, the need to seek diversity of knowledge, technologies and capabilities to remain internationally competitive, and demand issues such as information and proximity to markets. In addition, though firms have to deal with organisational issues that derive from the complexities of managing different activities and subsidiaries, in order to maintain cohesion and internal efficiency of the firm.

On the other hand, firms tend to concentrate a large percentage of their innovative activities in their home country. This is not surprising since knowledge creation, generation and dissemination is highly tacit, difficult to codify and of singular strategic importance to the competitiveness of the firm. This means that firms wish to exert as much control over the process by keeping $\mathrm{R} \& \mathrm{D}$ close to headquarters, or at any rate, in close proximity to a subsidiary which can assure an optimal level of monitoring and control over its activities. This acts to create some of the 'inertia' in the internationalisation of R\&D. In addition, there are a high level of interlinkages between, and interdependence on, the innovation systems of the host country which acts to create further 'inertia'. Nonetheless, national systems of innovation and industrial and technological specialisation of countries changes only very gradually, and especially in newer, rapidly evolving sectors - much more slowly than the technological needs of firms. Firms must seek either to import and acquire the technology they need from abroad, or venture abroad and seek to internalise aspects of other countries' innovation systems.

\section{The evidence: $R \& D$ activities of Norwegian firms}




\section{Data collection}

The survey of Norwegian $R \& D$ was based on a questionnaire that was developed in cooperation with Robert Pearce of the University of Reading. Although secondary data for Norway estimates that about 600 firms comprise the industrial R\&D performing sector, a large proportion of these firms are SMEs (Hauknes 1996). We selected Norwegian industrial firms with R\&D expenditures greater than NOK 10 million $^{7}$ and/or more than $10 \mathrm{R} \& \mathrm{D}$ employees, which gave us a sample of less than 50 firms. Firms that had been acquired by foreign investors, but remain autonomous (and therefore Norwegian controlled) were included. By excluding all foreign -controlled firms we were left with approximately 35 firms. Given the relatively small group of firms that meet our criteria, it was decided to conduct the survey through interviews, conducted with the head of the R\&D department or equivalent. No information that provides specific evidence of individual company strategy has been revealed in this study ${ }^{8}$.

\section{$\underline{\text { Firm and Industry Specific Issues }}$}

There are two aspects of the economic structure of Norway that are instrumental in defining the nature and extent of R\&D activity in Norway. First, Norway has traditionally competed on factor endowments (see Stonehill 1965, Hodne 1993, Reve et al 1992). Indeed, much of the industrial activity in Norway has evolved around upstream activity and value adding to resource-based sectors. According to Reve et al (1992) there are 4 strong industrial clusters, and these relate directly to its factor endowments: petroleum, hydropower, metals, and maritime industries. Other less 'complete' clusters -some of which have lost their competitiveness partly as a result of changes in comparative advantage in some natural resources - also derive from factor endowments, and include pulp and paper and seafood.

Second, there has been significant government intervention in the structure of Norwegian industry. These have aimed at explicitly creating new areas of industrial specialisation and have led to the creation of other incomplete clusters, such as telecommunications, pharmaceutical and information technologies. Such interventions have occurred consistently over the post-war period (and possibly even longer) through several means, which we discuss briefly below:

\footnotetext{
${ }^{7}$ At the time of the sample selection, NOK 7.5 = US\$1

${ }^{8}$ Given the relatively small sample size, the very specific nature of their products and competences, and the small number of firms in each industry, it is difficult to give a detailed overview of the firms included in our sample, without breaching confidentiality.
} 
(1.) The state has promoted the development of energy-intensive sectors, through the provision of cheap (and subsidised) hydroelectric energy. Although these subsidies have been drastically reduced, the consistent use of this subsidy is partly responsible for the competitive advantages of some of the traditional industrial firms.

(2.) There have been several waves of restrictions on the activities of foreign-owned firms in Norway, both through entry barriers to FDI, and through tariff and non-tariff barriers to imports ${ }^{9}$. These have served to keep the role of FDI in Norway to a low level for much of the $20^{\text {th }}$ century. Since the 1990 s both governments subsidies and restrictions on FDI and imports have drastically been reduced, and in many cases eliminated, due to both the GATT and EEA agreements ${ }^{10}$. The restrictions on FDI and trade have been abetted by the high level of state ownership in Norway. Although some privatisation has occurred, this has been rather minor, and mainly in sectors no longer considered strategic, such as in former defence related firms.

(3.) During much of the post world War II era, and up to the late 1980s, the Norwegian government has intervened in Norwegian industrial development through some level of import-substitution industrial policy, at different times targeting the development of certain sectors, as well as moulding particular firms into "national champions'"11. During each wave, fundamental components of industrial policy were: stateownership, technology transfer by foreign MNEs, and preferential treatment for Norwegian firms, firms with Norwegian partners, or firms that had transferred significant components of their technological activities to Norwegian locations.

These developments have had a significant effect on the industrial structure of Norway, creating what is essentially a dichotomous industrial structure. Our data suggests the classification of firms into two main groups, which are discussed below.

\footnotetext{
${ }^{9}$ There have been several waves of nationalisation of foreign-owned assets during the first half of the $20^{\text {th }}$ century. In addition, most German assets were acquired by Norway immediately after World War II. Most prominent was the acquisition of the majority ownership of Norsk Hydro by the Norwegian state (Stonehill 1965)

${ }^{10}$ It is worth noting that the OECD estimates that barriers to trade and investment are still on average at least double of those in most EU countries, and compared to countries such as Germany, UK and Italy more than three times as high (OECD 2000).

${ }^{11}$ From the $1950 \mathrm{~s}$, the focus was on heavy industry, particularly electro-chemical industries, electrometallurgical industries, ship building and the like. The primary asset -and backbone -of the industrialisation programme was the cheap and plentiful supply of electrical power. In the mid-1960s, considerable government investment was made in 'modernisation', with a focus on infrastructural projects, particularly telecommunications, as well as defence. The core focus was in new technologies, focusing on electronics related industries. In the words of one interviewee, 'up to 1980, Norway had the most heavily subsidised electronics
} 


\section{Group A: traditional industries and formerly protected firms}

Group A consists of what might appear to be two quite different sub-categories, but share several important characteristics. The first sub-category are firms in traditional, raw materialsbased sectors ${ }^{12}$. Many of these may be described as 'national champions', and have traditionally received a considerable amount of state aid. Indeed, the Norwegian state has considerable ownership in some of these firms, most notably, Norsk Hydro $\left(51 \%{ }^{13}\right)$ and Statoil (100\%). The second sub-category within Group A of firms still operate with a competitive advantage that derives partly as a result of protected markets (a result of former infant industry protection programs), or hitherto-protected sectors where foreign investment has either been discouraged and/or are (or were) nationally owned monopolies ${ }^{14}$.

\section{Group B: Specialised and technology-intensive companies}

The second group consists of firms that are engaged in more knowledge-intensive sectors, and can be regarded as science based ('non-traditional') firms. Although some of these firms have evolved from a supportive or related sectors to these natural-resource based sectors, they have gradually diversified or specialised into higher value-adding activities ${ }^{15}$. Others are firms which have always operated in specialised science-based sectors ${ }^{16}$.

Broadly speaking, our survey has observed that there is considerable difference in the way in which firms from these two groups undertake both their domestic R\&D activities, and the propensity to undertake international $R \& D$ activities. Group A accounts for $63.5 \%$ of the R\&D expenditures of our sample, and Group B represent $36.5 \%$ of the total $R \& D$

industry in the world'. After the OPEC oil crisis, the emphasis was on developing the petroleum industry (Nygaard and Dahlstrom 1992).

12 e.g., Metal-industrial sectors (such as Norsk Aluminium [aluminium], Elkem [ferro-alloys]), forestry sectors (Norske Skog [paper and pulp]), petroleum sector (Statoil, Norsk Hydro) and shipping/seafood sectors (Kvaerner [shipbuilding], Mustad [fish hooks, automated fish baiting systems, commercial bait]).

${ }^{13}$ As a result of Norsk Hydro's acquisition of Saga, the third major Norwegian petroleum company, the state's share in Norsk Hydro fell to $43.8 \%$ in 1999.

${ }^{14}$ This category includes companies such as Lilleborg and Norsk Jetmotor ${ }^{14}$, Dyno Chemicals, Telenor. Note that some of these firms have been acquired by foreign competitors as liberalisation has eroded some of their competitive advantages. For instance, Norske Jetmotor was acquired by Volvo Aero in 1999, and Dyno was acquired in 2000.

${ }^{15}$ An example is Jotun, which started by manufacturing specialised paints for the maritime industry, but has diversified into other paint technologies. Lignotech, began life as a wood pulping firm, but has moved towards the sale and development of wood-based extracts.

${ }^{16}$ Examples include Synthesis, which manufactures pharmaceutical intermediates, Navia Aviation, which produces aviation navigational aids equipment (acquired by Northrop in 2000), ASK-Proxima, which is engaged in the production of LCD projectors. Dynal, a spin-off from Dyno is one of the few commercially successful biotechnology firms in Norway. Laerdal manufactures highly sophisticated medical diagnosis equipment. Tomra dominates the world market for bottle recycling systems. 
expenditures of our sample. In general, Group A is also less internationalised in terms of sales, with foreign sales representing (on average) $59.4 \%$ of total sales, compared to group B where overseas sales account for $88.1 \%$ (Table 1).

***TABLE 1 ABOUT HERE***

Table 2 gives details of the distribution of our sample in terms of R\&D expenditure. Two things are obvious from this table. First, that our sample accounts for a large percentage of the formal $R \& D$ activities undertaken by private companies. Although the total $R \& D$ expenditures of the firms in our sample represents $63 \%$ of BERD, we estimate that approximately $10 \%$ of BERD is accounted for by foreign-controlled firms ${ }^{17}$. In addition, one of the largest Norwegian MNEs was unable to provide data on its total R\&D expenditure because it was undergoing massive restructuring, and thus was partly excluded (only one of its subsidiaries was included). We estimate that this firm alone may account for $3-5 \%$ of BERD. Thus, we estimate that our sample accounts for anywhere between 70 and $80 \%$ of all Norwegian controlled BERD ${ }^{18}$.

Indeed, as Table 2 shows, a very large percentage of the R\&D activities of Norwegian firms are undertaken at a rather small scale, even within our sample. Over $50 \%$ of our sample have annual R\&D expenditures of less than NOK 10 million. In terms of R\&D employees, there is a similar distribution: $56 \%$ of the sample had less than $50 \mathrm{R} \& \mathrm{D}$ employees, and $76 \%$ had less than 75 R\&D employees. Only $12 \%$ of the R\&D facilities have more than 200 R\&D employees.

\section{***TABLE 2 ABOUT HERE*** \\ ***TABLE 3 ABOUT HERE***}

In terms of industrial distribution, $38.5 \%$ of the firms could be classified as being engaged in low technology sectors, and 30\% in electronics and IT sectors (Table 3). Low technology sectors include food and beverages, wood and wood products, paper and paper products, and fishery equipment. The 'electronics-based sectors' include several specialist

\footnotetext{
${ }^{17}$ In particular, 4-5 foreign-owned affiliates (which include ABB, Siemens, Ericsson and Alcatel) account for an estimated NOK 1 billion in R\&D expenditures.

${ }^{18}$ Data from Statistics Norway suggests that there are approximately 600 firms that undertake R\&D in the business sector. This suggests that 400-500 firms account for approximately NOK 2 billion, which provides us with an average estimate of less than NOK 0.5 million per firm. These figures, although rough, allow us to estimate that approximately $80 \%$ of firms in Norway which undertake innovation have less than one full-time equivalent R\&D employee each.
} 
companies that manufacture control equipment for ships, and specialised fishing equipment such as sonar's, in addition to consumer electronics, telecommunications and medical diagnosis equipment.

Although Groups A and B are roughly equal in number of firms, corresponding shares of total worldwide sales are $93 \%$ and $7 \%$ respectively, and in terms of employment, the

figures are $84 \%$ and $16 \%$. However, in terms of domestic R\&D employment, Group A accounts for $70 \%$ and Group B for about 30\%. Table 3 also illustrates that a majority of firms (88.5\%) in Group A operate in the low tech sectors, while only $46.1 \%$ of Group B can be so classified.

These data make the following points. Group A consists of a firms which are large, which account for a large share of the sales and employment in Norwegian industry, despite representing a small percentage of the total firms in Norway, and are concentrated in low technology (and non-R\&D intensive) sectors. They also tend to be less internationally oriented in terms of sales. Group B firms are by and large SMEs, and have a higher propensity to be in more R\&D intensive sectors, but are more active in terms of overseas sales than Group A. In terms of R\&D, Group A firms have on average only $5.0 \%$ of their $R \& D$ employees outside Norway, compared to $28.9 \%$ for Group B, despite the fact that on average Group A firms are on average several times larger in terms of their total operations (Table 1). These differences not only reflect the extent to which these traditional and protected firms are embedded into the local economy, but also the fact that most of these companies are engaged in low $R \& D$ intensive sectors, while Group B firms are engaged in more $R \& D$ intensive sectors. In addition, the differences are even greater in terms of overseas activities: the ratio of R\&D employees to total worldwide employees is 3 times higher for Group B than Group A, while the ratio of foreign $R \& D$ employees to total worldwide $R \& D$ employees is 6 times greater for Group B than Group A. Indeed, even in terms of absolute number of overseas R\&D employees, Group B has almost 3 times as many employees as Group A, despite the fact that in terms of revenues, they account for slightly over $10 \%$ of the total revenues of our sample.

***TABLE 4 ABOUT HERE***

To what extent do these differences in $\mathrm{R} \& \mathrm{D}$ internationalisation reflect differences in the internationalisation of production and sales? Table 4 gives details of the activities of our sample of firms with regards these three elements. These percentage reflects the number of 
regions in which firms have sales, production or $\mathrm{R} \& \mathrm{D}$, and not the intensity or the value of these activities ${ }^{19}$. The evidence indicates the following facts. First, that there is no significant difference in the extent of overseas of sales and production, apart from the fact that several of Group A firms had no overseas activities. However, on the whole, Group B firms were more evenly involved across regions. $85.7 \%$ of Group B firms can be regarded as being 'global' in terms of their sales activities, with sales in at least 5 of the 6 non-home regions, compared with just $45.5 \%$ of Group A firms. A larger percentage of Group A firms were involved in production in the EU compared with Group B, but the difference was marginal. Firms in Group A generally regarded themselves as 'eurocentric' ${ }^{20}$. In contrast, Group B firms took a more global view of their competitiveness. In terms of production, Group B firms were more highly concentrated in three regions: the EU, North America and Asia, but only $7.1 \%$ could be regarded to be 'global', and only 50\% had 'multinational' operations. Group B firms undertook production in many more locations, and $18.2 \%$ of the respondents were 'global' in their geographic spread, and 63.6\% 'multinational' in scope.

With regards R\&D, however, Group B firms had a higher overseas presence, with $42.9 \%$ of firms with R\&D in both the EU and North America. Corresponding figures for Group A are $27.3 \%$ and $9.1 \%$ (Table 4). 35.7\% of Group B firms could be regarded as 'multinational' in terms of geographic spread of R\&D compared with $9.1 \%$ for Group A.

As we have discussed in a previous section, a large proportion of $R \& D$ activities (both home-based and international) have as a primary purpose the objective of supporting production activities. Norwegian industry is a relatively newcomer to outward FDI, having only begun to invest in earnest in the 1970s (Hodne 1993). Thus, although there is a high dependence on overseas sales, production has only begun to be relocated much more recently. To some extent, therefore, it is reasonable to expect a low overseas intensity of production, as has been the case with Japanese FDI - much of the activities of Japanese firms had, until the late 1980s concentrated on assembly-type activities (Dunning and Narula 1994) or salessupportive activities. Likewise, the level of foreign $R \& D$ intensity was also low. In the case of Group A, (and especially traditional industries), FDI was undertaken to access lower cost resource inputs as the cost of factor endowments rose in the 1970s. Many of these companies' products are commodities in nature, and the increasing cost of such activities has led to a dispersion of their production. As one manager said,

\footnotetext{
${ }^{19}$ Many of the interviewed firms were unwilling to provide data on level of sales or production for their foreign affiliates.
} 
"It is important to be close to our markets....we have to think about the breakeven point between transportation and the benefits of consolidation of our market units...we are a costdriven industry, so it is important to be near our customers".

However such resource-seeking FDI tends to have very low R\&D activity associated with it, if any, and the nature of the industry means that R\&D can continue to be done primarily at home. In the case of Group B firms, their small size has also limited their international activities.

Taking Table 1 and 4 together, it is possible to say that Group A firms have decentralised their production activities but continue to concentrate their R\&D activities, while Group B firms have a more centralised production, but more geographically dispersed $R \& D$ activities. It is important to note that the size of Norwegian-controlled overseas $R \& D$ activities are quite small in terms of absolute size. The largest R\&D facility outside Norway has less than 65 R\&D employees (Group A, laboratory located in the EU). In North America and the EU, the two regions with the largest number of $\mathrm{R} \& \mathrm{D}$ facilities, the total number of R\&D employees are 163 and 130 respectively. In other words, these facilities are limited in resources, and the intensity of activities they can undertake.

Thus, the differences in industrial structure of the Norwegian environment faced by the two groups of firms plays a significant role in determining their domestic R\&D activities, and their international involvement. One of the primary questions in the survey was "how important are the following factors to your decision to maintain $R \& D$ laboratories in Norway?", based on a five-point scale. These tendencies are apparent from Table 5, which gives details of responses by both groups of firms.

\section{***TABLE 5 ABOUT HERE***}

Group A firms clearly consider proximity to production units/customers as an important determinant of the location of their R\&D activities in Norway, with $66 \%$ indicating that it was of major or crucial importance. As discussed above, a majority of their strategic value-adding facilities remain concentrated in Norway, and it is reasonable to expect that this plays an important role in keeping their $R \& D$ centralised at home. In addition, a high concentration in process industries makes decentralisation less important. By contrast, only $28.6 \%$ of Group B firms felt it was a significant factor, despite the fact that most of these

\footnotetext{
${ }^{20}$ When asked to estimate their position vis-à-vis their competitors, many of the respondents said, 'we are number.. in Europe', but these respondents were generally unable to indicate their global ranking.
} 
firms also maintain a significant (and major share) of their production activities at home. As we have discussed in the theoretical discussion, their technology-intensive nature means that their need to seek complementary assets and specialised resources increase their need to internationalise.

For similar reasons, access to raw materials and inputs is a much more significant factor for firms in Group A, with 33.3\% of firms regarding it of major or crucial importance to maintaining R\&D facilities in Norway (Table 5). This reflects, once again, the importance of input costs to commodity based industries. In addition, former import-substituting firms have enjoyed ownership advantages which are location-specific, and not as easily duplicated in overseas locations. With reduced or withdrawn state protection, these firms are more conscious of the input costs, since profit margins have been considerably affected by competition (most of which comes from inward $\mathrm{FDI}^{21}$ ). As for Group B firms, only $7.1 \%$ considered Norway as an important location for R\&D because of easy access to inputs. In some cases, as much as $80 \%$ of their inputs are imported from countries in other parts of Europe, and the far east. They are engaged in high value-added sectors, and the transportation costs are negligible in relation to their costs. In general though, for both groups (but particularly for Group B) in terms of $R \& D$ activities, inputs are a very small cost of innovatory activity.

Norwegian firms do not, in general, consider Norway to be a useful place from which to monitor the technological activities of competitors (Table 5). Indeed, when asked to list their major competitors, none of the firms in the survey included any firms located in Norway $^{22}$.

Both groups of firms of firms showed a strikingly similar response regarding the proximity of suppliers to the location of $R \& D$ (Table 5). Despite the similarity, the reasons for undertaking outsourcing of the two groups is considerably different and reflects technologyspecific characteristics (see Narula 1999b for a discussion). In the case of traditional industry firms, for instance, because of the maturity of their sectors, and the fact that competition is not

\footnotetext{
${ }^{21}$ Kvinge and Narula (2000) examine the growth of foreign companies in Norway, and note that there is a higher concentration of foreign firms in sectors that were formerly protected.

${ }^{22}$ Although inward FDI into Norway has grown quite considerably over the last two decades, a considerable amount of FDI is still import-substituting in character, and tends to have low R\&D intensity, except where access to Norwegian markets was provided with the condition that R\&D be undertaken. As we have noted earlier, there is a high concentration of R\&D activities in four foreign MNEs, which are engaged in domestic production (again as a result of previous import-substituting and targeted industry initiatives) of capital equipment for power generation and telecommunications. However, a study by Benito (2000) noted that $42.7 \%$ of the firms in his survey of 255 foreign subsidiaries regarded development as an activity undertaken in Norway, and $25.1 \%$ regarded research as part of their profile. Given the high concentration of R\&D expenditures by foreign firms, It would suggest that the $R \& D$ activities of a majority of foreign MNEs is on a rather small scale.
} 
based on access to unique technologies, a higher level of external technological outsourcing is feasible. Competitive advantage in these industries generally derives not from technology per $s e$, where the products are 'generic', but from marketing and economies of scale. Indeed, one firm explained:

"We have nothing to hide. We believe in sharing all our technologies, because we don't really have anything special. There isn't much that our competitors don't already have, and its really a small circle - everyone knows everyone else - we have all been in this industry a long time. Things change very slowly, and we make most of our profits from downstream activities. Maybe our core asset is our marketing and logistics department."

\section{****TABLE 6 ABOUT HERE***}

Table 6 gives the distribution of level of R\&D outsourcing undertaken by the different groups of firms. Group A firms use an average of $27.4 \%$ of their R\&D budget to undertake $\mathrm{R} \& \mathrm{D}$ outsourcing and alliances, compared with Group B, who on average spend $18.2 \%$ of their budget on non-internal R\&D. There are two reasons for this significant difference. First, there are demand related reasons. It is important to remember that Group A firms are raw materials and intermediate goods suppliers, and tend to undertake a lot of collaboration in $\mathrm{R} \& \mathrm{D}$ simply because they need to do so: it is in the nature of being a supplier to subsidize the $R \& D$ of the customer:

"If there is a new [standard], for instance, its good for us. We have to design new machinery or adapt existing equipment for our major customers. It means more orders. But it also means we have to make the R\&D investment. If we don't, a competitor will, and they will get all the orders. Margins are tight, because we have a long-term relationship, so we never question the wisdom [of subsidising the R\&D of customers]."

Second, Group B firms are also less able to outsource R\&D to other firms because they are engaged in more rapidly-evolving technologies, and are close to the state-of-the art. Thus, to use non-internal means would require giving away their competitive advantage: to give a supplier firm enough knowledge to act as an efficient supplier might create a possible competitor (Narula 1999). In addition, SMEs are also constrained by resources as to the number of technologies in which they can maintain in-house competence. Most technology intensive sectors nowadays require firms to be multi-technology firms. Besides, not all technologies are equally strategic.

Outsourcing for SMEs in general is not a matter of choice, but of need. They are forced to consider cost issues to a greater extent than larger firms. In addition, SMEs in our survey are engaged in (more) competitive sectors, where technological change is much more 
rapid, and where they have to compete with foreign MNEs with more resources. It is these companies that dictate the rate of new product introduction. New products must be generated at the same rate as the other players if these firms are to survive.

The results suggest there are distinctive differences between the two groups. Group A firms operate in less technology intensive sectors, and are, by and large, in process-type industries and based on traditional commodity type inputs, in which Norway has traditionally had a comparative advantage, and in which clusters exist, and for which the domestic innovation systems are more comprehensive ${ }^{23}$. Although changing factor costs, and the high costs of transportation relative to value added have promoted international production, $R \& D$ is by and large concentrated at home. This is in part a function of the industry these firms. Firms have less need to be geographically proximate to their production activities compared to more R\&D intensive, rapidly evolving industries. In addition, though, because of these technological characteristics, firms can seek to acquire assets through outsourcing, more so than Group B firms.

As for Group B firms, they are engaged in more technology-intensive sectors, and are predominantly SMEs. These are sectors where Norway has not got a comparative advantage. However, a number of them operate in industries or operated in sectors in which clusters and/or competitive advantages existed in the past, or which were targeted sectors in previous industrial policy. Thus, while fragments of clusters or 'incomplete' domestic innovation systems exist for these firms, by virtue of the fact that their markets are more global than European, they have sought to internationalise relatively more in terms of $R \& D$, since they need access to a larger variety of technologies, and which are not as easily available through arms-length modes such as technology outsourcing and alliances. In addition, important demand factors exist, as in many cases they act as suppliers to larger firms, many of which are not based in Norway. However, they demonstrate low level of overseas production in terms geographic spread. This may be a result of one of two factors. First, by virtue of their smaller size, they simply cannot afford to internationalise to the extent that they might prefer. Second, because of the more knowledge-intensive nature of their activities and their dominant market positions, transportation costs do not play as critical a role in their location decisions.

\section{'Systemic' Lock-in: dependence on the innovation system}

\footnotetext{
${ }^{23}$ Although this is not always the case, some firms have also enjoyed hitherto protected domestic markets.
} 
The last section examined the general trends with regards to the internationalisation of Norwegian firms, and submitted that the low level of Norwegian-controlled overseas R\&D was determined to a large extent by the industrial structure and policies of Norway. The twotrack nature of Norway's firms, both in terms of R\&D intensity and size clearly reflects itself in the non-internationalisation of R\&D. In addition, we suggested that home country factors play a decisive role, in particular those associated with the innovation systems of Norway. In this section we explore more explicitly a few aspects that cause this 'inertia' of $R \& D$ associated with the home country innovation systems. It is clear from the preceding discussion that although there are differences between the two groups, even Group B firms are also home-country focused in their R\&D activities. A majority of the firms in both groups, for instance, regard the technical and scientific infrastructure in Norway to be an important factor for undertaking R\&D in Norway (Table 5). In this section we will try and examine this issue closer.

It is not within the scope of the current paper to make a thorough analysis of Norwegian innovation systems, but to illustrate our primary thesis that home country effects play a significant role in the 'inertia' question. In particular, we focus on two issues and their influence on the location of $R \& D$ activities of Norwegian firms: the institute and university sector, and the role of the state in terms of funding and policy. Indeed, these two are closely intertwined, and although there are other aspects of the innovation systems that have some bearing on the location of $R \& D$, for reasons of space these will suffice in illustrating our arguments.

As in all countries, the primary participants in the Norwegian $R \& D$ system comprise of three players: private sector firms, the higher education sector, and the institute sector (Hauknes 1996). These institute and universities sectors together undertake roughly the same level of $R \& D$ activities in terms of $R \& D$ expenditure as the industry sector ${ }^{24}$. The significance of the institutes and universities is derived from the fact that they form the major means by which the state - directly and indirectly - subsidises R\&D activities. $62 \%$ of the funding of the institutes and $88 \%$ of that of the universities come from public sources (NIFU, 1999).

The level of subsidies provided by the state are by themselves not exceptional, but the active and central role that the state has in determining how these funds are spent, and whom they are directed towards. As we have highlighted before, the state has always played a strong

\footnotetext{
${ }^{24}$ in 1997 the universities had an expenditure of NOK 4845 million, the institute sector of NOK 4826 million, and the enterprise sector of NOK 8517 million.
} 
interventionist role in Norwegian industry ${ }^{25}$. The importance of government intervention was evident from our interviews, although neither group of firms considered government pressure as a primary factor in maintaining $R \& D$ facilities in Norway (Table 5). However, Group A firms, regard government pressure to maintain $R \& D$ activity as a much more important factor than Group B, with a quarter of the respondents regarding it as being of major or crucial importance - unsurprising given the fact that many of these firms are either state-owned or national champions.

The different attitudes towards R\&D may also partly be as a result of the way in which public subsidies are provided to industry. A large share (42\% in 1997) of R\&D expenditures are provided by the public sources. Until 1992, funding of R\&D was undertaken by a variety of research councils, each controlled by different ministries. The Norwegian Research Council (NFR) was established as an attempt to bring together under one umbrella all the various R\&D funding and policy making agencies (Skoie 1997), thereby improving coordination, and increasing efficiency. At the same time, the objective was to improve the links between basic and applied research. However, ministries still approve and fund projects independently of the NFR - this is indicated by the fact that the direct funding of industry by the NFR is only about $25 \%$ of the total public funding of industry R\&D (NIFU 1999) ${ }^{26}$. The structure of funding towards the larger 'national champions' is evident. The objectives of various programs is steered by committees where managers from these companies have a significant presence, and they are thus able to influence the design of research themes. Smaller companies tend to have more difficulty in accessing funding directly, partly because of the lack of transparency of NFR programs, and the large amount of bureaucracy ${ }^{27}$. A manager of one of the larger firms said,

"NFR should cut down on bureaucracy and paperwork - big companies like [ours] can handle the amount of effort it requires. But companies which really need the funding, are not able to

\footnotetext{
${ }^{25}$ The extent to which the state continues to intervene is highlighted by a recent development, where Norsk Hydro decided to sell its aquaculture business to a Dutch MNE, apparently, despite the objections of the Norwegian government. Labour, the Centre Party and the Christian Democrats all expressed views to the effect that this sale could affect Hydro's chances of receiving new shares in the State Direct Financial Interest (SDFI) in the petroleum sector (Dagsavisen, 6 April 2000).

${ }^{26}$ Some of this funding goes through the Norwegian Industrial and Regional Development Fund (SND). The SND is not primarily oriented towards supporting R\&D, but is concerned with firm development, particularly in promoting their location in the (non-urban) regions of Norway.

${ }^{27}$ Even though a large amount of funding from NFR is ostensibly earmarked for SMEs, the general consensus from interviews was that much of the funding for SMEs was directed towards projects which involved activities by SMEs in their role as suppliers to large firms. In addition, the definition of SMEs used in Norway - less than 200 employees - excluded a large number of internationally competitive companies from accessing funds. However, because of the way in which data is collected, evidence for this is primarily anecdotal (see Christiansen, Moller and Smith 1996).
} 
handle this...it pays to have professional people who are very [skilled] in seeking money...big companies can always make your proposal directed to [what is advertised in the program descriptions], because they helped to design the programs...small companies do not have these possibilities..."

Another firm said that, "All the paperwork [for the NFR] makes [the funding we get from the NFR] almost not worth it. But we have to, because we must be 'invited to the party'. It's a club, and we can't afford not to be a member of this club."

The survey enquired about the average level of NFR funding made available to these firms during the last 5 years. Firms from Group $A$ as a whole are afforded more R\&D subsidies than those engaged in newer, competence-based technologies and sectors. As Table 1 shows, firms in Group A received a larger share of public share of R\&D funding: $3.0 \%$ vs. $1.2 \%$, on a weighted average basis $^{28}$. These figures exclude direct and indirect subsidies channelled through other agencies. It should also be noted that Group A includes a number of former monopolies, which have had a drastic reduction in their subsidies in line with conditions imposed by the EEA and WTO agreements and which have a weighted average NFR subsidy of just $0.6 \%$.

The Norwegian higher education system sector consists of four universities and a number of 'scientific colleges' which provide tertiary education at a university level. Although all perform R\&D type activities, only one university dominates postgraduate engineering and technology-related education: the Norwegian University of Science and Technology (NTNU). It graduates upwards of a 1000 engineers with masters level education, and $130 \mathrm{PhD}$ 's in engineering every year. These provide the backbone of R\&D personnel in Norwegian research establishments. The University of Oslo (UiO) plays a role in providing R\&D personnel in basic and natural sciences, as well as information technologies, but its contribution is clearly secondary to that of NTNU. NTNU, which is located in Trondheim is also intimately linked with SINTEF, the crown jewel of the institute sector, providing a considerable part of the laboratory facilities for SINTEF. In addition, about 180 NTNU professors are employed as scientific advisors to SINTEF. NTNU's links with industry are unparalleled by any other university in Norway, accounting for an estimated $15 \%$ of the total amount of R\&D outsourced (in terms of expenditure) by our sample. This figure does not include funding which comes through projects undertaken jointly by SINTEF and NTNU.

The institute sector consists of approximately 15 technological research institutes and 30 social research institutes, and reflects the various stages of Norwegian industrial policy 
over the post world war II years. They can be classified into 4 main groups. First, there are the 'collective' industry-specific research institutes. These are based around particular sectoral interests. For instance, the pulp and paper industry sponsors the pulp and paper institute. Second, there are the 'modernisation' institutes which were established as a part of the policy strategy to upgrade and develop particular industries which were deemed as essential to create a modern industrial sector, beginning in the 1950s. The most prominent of these being the Norwegian Defence Research Institute (FFI), the Central Institute for Industrial Research (SI), Telenor (TF) and the Institute for Atomic Energy (IFA). The third group are the regional institutes which are linked to local university-level colleges with the intention of developing and supporting local industry in the various regions of Norway, and linking them to the regional tertiary level colleges. The fourth group of institutes evolved in response to new targeted industries (in particular petroleum, and later electronics), but over time have evolved and merged, and are now based around what is essentially now SINTEF. The SINTEF group was established by the Norwegian Institute of Technology (NTH), the predecessor to NTNU, in 1950 in response to the government's decision to establish SI (Hauknes 1996). By the 1970s, a number of the institutes had lost their raison d'etre, for a variety of reasons. A decline in defence spending and the end of the cold war has reduced the strategic importance of IFA and FFI, while TF, became part of Telenor, the state-owned telecomm former monopoly. Other institutions from the first and second group also merged with SINTEF. The SINTEF group has evolved to what is arguably the largest R\&D laboratory in Northern Europe (Skoie, 1997), with over 1800 employees (84\% of whom are technicians, engineers and scientists) and a turnover of almost NOK 1.5 billion. It is by far the largest R\&D performer in Norway. It undertakes roughly $60 \%$ of the R\&D outsourced by our sample, whereas all the other institutes and universities (excluding NTNU) combined undertake less than $15 \%$ of total research outsourced by our sample, and probably closer to $10 \%$. Foreign institutes account for approximately 5\%. The link between SINTEF and NTNU is quite clearly a strong one, and the two cannot be viewed as separate, given their joint R\&D facilities and shared staff, and the historical link between the two. SINTEF is organised 8 research $\operatorname{areas}^{29}$, and also controls 4 stock research companies ${ }^{30}$. Given the closeness of

\footnotetext{
${ }^{28}$ Weighted averages adjust for the effect of smaller The unweighted average percentages are $6.3 \%$ and $3.7 \%$ for Group A and Group B respectively.

${ }^{29}$ As of 1999, these were as follows (approximate turnover given in brackets): Applied chemistry (NOK 148 million), applied mathematics (NOK 36 million), civil and environmental engineering (NOK 168 million), electronics and cybernetics (NOK 89 million), industrial management (NOK 146 million), materials technology (163 million), telecom and informatics (NOK 105 million), medical (NOK 101 million).
} 
SINTEF and NTNU, and the high concentration of non-firm R\&D activities that are industryoriented in these two players (between 70 and 80\%), it is practical to view them as a singe entity, sometimes referred to here as the SINTEF-NTNU axis. The primary rationale for the very strong, centralised (and concentrated) nature of the institute sector in Norway has been to create economies of scale and scope in research. This reasoning is still in vogue today. As a manager at SINTEF explained,

"There are a large number of SMEs in Norway that cannot afford to maintain dedicated R\&D facilities of the scale and scope that is required to compete with their international competitors. [In addition]...doing so would mean that facilities and resources would be underutilised. SINTEF can undertake similar activities for many firms at the same time, and thus be cost and resource efficient".

This policy of centralisation of research was meant to allow firms to maintain a smaller amount of internal R\&D, and rely on external (domestic) sources of research, in particular, SMEs. Indeed, funding by the NFR to firms is largely provided with the understanding that these funds will be utilised at one of the Norwegian research institutes, and not abroad. This means that broadly speaking, smaller firms undertake only market-related development activities, leaving the applied research and development to the institutes ${ }^{31}$.

This high centralisation of activities also has a very important centripetal effect on R\&D. Almost all the technical personnel engaged in R\&D are graduates of NTNU. $70 \%$ of the managers in my interviews (both firms and institutes) were also graduates from NTNU. On the one hand, this creates a sort of informal network between firms, as most of the personnel know each other, or know of each other, allowing for a greater flow of knowledge between firms and between firms and institutes.

Firms (or more accurately, technical personnel in these firms) are likely to recruit other engineers and scientists who come from this network. In addition, the larger firms have considerable influence on the curriculum and nature of the educational system within NTNU, and are thus able to influence the quality of people. One manager put it nicely,

"Norway is very important to us, not because Norwegians are smarter than other people, but because we know the culture here, and we know where to get people...it's a practical

\footnotetext{
${ }^{30}$ SINTEF petroleum research (100\% owned, SINVENT (100\% owned), MARINTEK (jointly owned with Veritas, and the ship industry association), and SINTEF energy research (jointly owned with energy research organisation and the electrical industry association).

${ }^{31}$ In theory, this frees the universities to focus on basic research. However, the consistent under funding of universities means that competent researchers at universities also compete for research funding from NFR and others, and engage in more applied research than basic research. In addition, funding for open-ended (and more basic, non-project related work) R\&D by SINTEF has also been considerably cut over the years, and they also undertake less basic research.
} 
issue....we can put pressure on the universities to change their profile. We could not do this elsewhere without considerable time and effort...".

However, it should be noted that the ability to influence the curriculum is something that only Group A-type firms have, given their larger size and economic clout. Larger firms tend not only to get graduates tailored to their specifications, but also are able to recruit the best students. Large firms also invested in sponsoring visiting professors and researchers from other countries in research themes that they felt needed to be developed, something which SMEs could not afford to do. One firm explained that the main reason for having $R \& D$ facilities in Trondheim was to be close to NTNU,

"Trondheim is the capital of research in technology....we have found that we can recruit from the top shelf [because we are located in Trondheim]. We find the best candidates before they finish. We finance [the dissertation work of] individuals whose research interests match ours...[because we know the professors] we know who are the best [candidates], and establish [a] connection with them early. It is a major responsibility [of mine] to handpick the best people every year".

Indeed, both Groups regarded Norway very highly in terms of availability of high quality research professionals, with $91.6 \%$ of firms in Group A, and 85.7\% of firms in Group $\mathrm{B}$ regarding it as of major or crucial importance (Table 5).

The evidence would suggest that Norwegian firms are 'locked-in' to the Norwegian innovation systems, and this restricts their activities, both on a technological and an organisational sense. On an organisational level, firms are heavily dependent on the Norwegian system, since they have traditionally relied on these assets, and are reluctant to try new options. Inter alia, this is because the search procedure to find an optimal alternative source is expensive, and the high costs and considerable time required to develop new linkages with alternative research institutions makes such an attempt out of reach of all except the largest firms. An a priori familiarity with outside sources does, of course, help. Several of the $R \& D$ managers interviewed who had studied in other countries were more inclined to using non-Norwegian institutes. One of the Swedish -trained manager of an SME (which no longer undertakes any work with the SINTEF-NTNU axis) said,

"When I first took over we spent NOK 10 million in [Norway], but we didn't get anything out of it, so we now use research institutes in Sweden and [other countries] where I know.. [where to go], and where we will get what we need."

Firms from both groups that have more international experience in terms of production activities and are larger in terms of size are also more likely to use alternative (which in this case means non-Norwegian) sources of R\&D suppliers and new employees. They have learnt 
about alternative innovation systems and are more familiar with operating in the host environments, because they are linked with them, and have the resources to develop these linkages further. However, the organisational lock-in with Norwegian systems is not necessarily forsaken:

"we are currently establishing a technical centre in the US - but we are trying always to strengthen with SINTEF and NTNU. We sponsor people from Trondheim to go abroad to do joint research, give lectures, and attract professors and researchers to come from [these other institutes]. We sponsor Norwegian students to study [at other institutions abroad where we have identified competences that we need]".

In terms of costs ,SINTEF, NTNU are worth it - if you can keep them on track. ...but they have more competition - we have found more and more institutes outside [Norway] with competence. But of course [SINTEF-NTNU] are Norwegian and they are close by....nonetheless, we are not increasing their share [of our R\&D outsourcing efforts], but increasing [our purchases from] outside Norway.

The second aspect of lock-in creates a 'technological inertia'. As we have highlighted earlier, technological specialisation of countries changes only very gradually. Norway has over a period of almost a century focused on low-technology, resource based sectors. Although knowledge-intensive sectors have received considerable government attention, these sectors (in particular those associated with electronics-based sectors) have not developed into a large enough agglomeration, and are largely incomplete clusters, nor has the government succeeded in creating any large national champions. This situation has probably not been helped by the change in the emphasis in policy over the decades. For instance, the most recent shift since the 1980s has been from telecommunications and electronics to software. Many of the companies that have survived these 'reshuffles' have either become associated with one of the more complete clusters, or they have been acquired by larger major international players in their industry. The following observations by Group B companies illustrates the unevenness of the system:

"[the quality of] education is very bad, particularly in our areas of technology. Research funding in [our] industry has been reduced to $40 \%$, universities are lacking resources, and professor salaries are so low that recruitment is impossible in universities. Many of the students...don't meet the standards for taking up technical education...."

"There is...far too much raw-material based focus [in the way research is funded]. We as a small country, with high level of education, we should be competing much more on competence base than raw material base. The only so-called competence based areas [in Norway are traditional sectors] like shipping...we are really pumping that oil, digging that mine...not adding value to the resources...its the wrong way of using the resources". 
"The government needs to promote reasons to stay - if not for our history [our company] would be better off somewhere else. The lack of competence level....is coming from the [low quality of] education. It won't help to pour in more money [to subsidise R\&D], if the [human resources] to receive it are not competent to deal with it. [in R\&D we] need to start with the people, that there is someone professional to do the thing. Of course there are good professionals [in our area] in Norway, but this is in spite of the government. "

In addition though, because of significantly large players in the traditional industries, competitiveness built over a long period, their ability to shape the Norwegian system of innovation to their needs, Norwegian firms in these sectors are locked in a virtuous circle of technological competitiveness (Cantwell 1987). In other words, firms are technologically locked-in to superior (or at least state-of-the-art) technologies.

While the outcome of 'technological inertia' may be positive, it may just as easily lead to a vicious circle. Where clusters exist and the threshold level of support and synergies exist from (and between) suppliers and related firms, institutions, universities, government, and resources, thereby establishing technological state-of-the-art, then the outcome is superior and optimal. Where these factors are incomplete, or interact in a sub-optimal way, then the technological level in the location may be locked into inferior (or lagging, non-state-of-theart) technologies. Where a critical level of competence does not exist, firms are also locked in to inferior technologies. This is enhanced in the case of new technologies. By virtue of being a small country with one (albeit large) technological university, there are a fewer number of professors, and the research themes and approaches of their research groups are constrained. The same, rather small group of professors, will, simply by the path dependence of their specialisation, tend to generate new PhD's with roughly the same interests and skills. In other words, the lack of diversity by virtue of a small group of researchers limits the diversity of new ideas and technologies, even where a high competence level exists. Where the system is supported by inward technology transfer by MNEs which sponsor cooperation between foreign sources of knowledge and the domestic sources, this problem is minimised. It helps, of course, that these areas are relatively slow-evolving, mature sectors. Where technological change is rapid, and firms do not have the resources to help augment the domestic technological base, firms will necessarily seek external sources directly, without improving the domestic scientific infrastructure. Even for Group A firms, getting the right people is not as easy. As one manager explained, its not just educational levels that count, but experience:

"Its easy to get people from universities, but we prefer people who have been working 1-3 years after their $\mathrm{PhD}$, because its takes $2-3$ years before they are really producing... Its 
becoming more difficult to find people with experience....we are increasingly appointing people from outside Norway".

Some companies have tried to resolve this matter by seeking to bring in expatriate researchers, but this option has had limited success. In certain areas like biotechnology, there are simply not enough domestic researchers available. One firm recently advertised repeatedly for new scientists in Norway and abroad, but only produced one applicant from abroad, who is of Norwegian background, and no responses from within Norway. The reasons for this are associated with relatively low salaries (in purchasing power terms, and relative to salaries offered to similarly qualified researchers in other countries), the climate and the remoteness of Norway. Several Norwegian laboratories have, nonetheless several expatriate researchers.

"To have the right people, we have to pay the market price...Norwegian salaries are lower...it is easier to move to London or Paris or Rome where we [would be] much closer to sources of educated and experienced people...".

\section{Policy implications and conclusions}

While accepting the fact that strategic and other firm-specific factors are central to explaining the internationalisation of innovatory activities, we have argued here that the industrial specialisation of firms and the location of their technological activities is heavily influenced by country-specific factors. This is part of a wider phenomenon: firms of all nationalities display an 'inertia' in $R \& D$ internationalisation and are more reluctant to internationalise R\&D than other aspects of their value-adding activity, such as sales and production. The level of internationalisation is also industry-specific. However, in the aggregate, firms of some nationalities show a higher reluctant to do so. It has been our objective in this paper to explain why.

We have argued here that this added inertia is associated with the nature of the innovation systems of their home countries, and the level to which these firms are locally embedded. The level of internationalisation reflects the extent to which firms are interdependent and co-dependent on domestic institutions and policies which have not only formed them - and with which they are most familiar- but which they have also helped create.

The case of Norway illustrates this well. Norwegian industry can be viewed as consisting of two groups of firms with distinguishably different characteristics. Group A consists primarily of national champions and tend to be large, engaged in traditional resourceintensive sectors in which Norway has had a historical comparative advantage. They enjoy a certain amount of government patronage, and are highly embedded in Norway. It can be 
argued that the NSI of Norway has been built around these firms. It should be noted that these firms are largely successful business enterprises, and their larger size and longevity is not unrelated to this. Group B firms operate in more technology-intensive, science based sectors, and tend to be SMEs. These firms have evolved in part as a result of various industrial policy initiatives over the post-war era to create clusters in more knowledge-intensive sectors, but which -as industrial clusters - failed to achieve sufficient impetus. Group A firms are relatively much less internationalised in both sales, production and R\&D than Group B firms.

We have argued that, because of their economic and political significance, Group A are able to adapt the domestic NSI to their changing needs, while Group B have not had the resources to do so. In addition though, the industrial specialisation of Group A is in mature, slow-evolving industries, while Group B are in more rapidly developing sectors, which require multiple competences. Thus, they have a greater need to seek additional resources abroad.

We need to emphasise here that our analysis of inertia in $R \& D$ is not to suggest whether it is 'good' or 'bad' per se: Certain sectors are more amenable to internationalisation than others, and as long as the NSI meet the needs of home-based firms, there is nothing 'wrong' with a systemic interdependence between actors within the NSI, and a consequent home-bias. However, when the NSI does not meet the needs of firms in certain industries, it affects their technological competitiveness. When firms exhibit systemic lock-in to an NSI and it retards or hinders firms' attempts to compensate for weaknesses in the domestic NSI by tapping other locations' NSI, it can be 'bad'.

We have suggested that SOEs can, under certain circumstances be locked in a vicious circle of technological accumulation, or what we have termed 'technological inertia'. No country can possibly expect to provide world-class competences in all technological fields. Even the largest, most technologically advanced countries cannot provide strong innovation systems to all their industries, and world class competences in all technological fields. The cross-border flow of ideas is something that has always been seen as fundamental to firms, and this imperative has increased with growing cross-border competition, and international production.

However, some countries have regarded imported technologies as a sign of national weakness, and have sought to maintain and develop in-country competences, often regardless of the cost. The strategy of technological self-sufficiency is increasingly untenable as SOEs have limited resources. Norway, again, illustrates this well. As a SOE, there are by definition a limited number of researchers, and assuming a normal distribution, there are an even smaller 
number of world-class professors, scientists and engineers. It is reasonable to expect that these researchers will produce like-minded graduates, thereby doubly constraining the number of new ideas. Relying on in-country competences may lead to a sub-optimal strategy, especially in this age of multi-technology products. Group A firms avoid this by sponsoring the flow of new ideas by importing researchers to supplement Norwegian researchers and encouraging Norwegian scientists to travel abroad to collaborate. SMEs in Group B cannot afford to do so, and are more likely to internationalise their innovative activities as a means to seek new ideas. However, even this option is expensive, since SMEs are limited by the amount of resources they can commit to the internationalisation of $R \& D$, because $R \& D$ is not only costly and risky, it requires a certain minimum scale to be efficient.

In addition, though, even Group B firms are reluctant to internationalise, because of what we have termed 'organisational inertia'. Norwegian firms and researchers are members of the same - relatively small - 'club' and have developed informal relationships over a long period of time. The need for alliances and other more formal interactions between buyers and suppliers is considerably reduced, since a high level of trust and interdependence already exists, and in a small community, costs of shirking are very high. Furthermore, managers and scientists are not always familiar with other options, and are more risk-averse than might otherwise be the case.

Despite these factors, there has been a growing $R \& D$ internationalisation, admittedly still at a nascent stage. This is because there is a growing mismatch between what home locations can provide and what firms require. In general, national innovation systems and industrial and technological specialisation of countries changes only very gradually, and especially in newer, rapidly evolving sectors - much more slowly than the technological needs of firms. Firms must seek either to import and acquire the technology they need from abroad, or venture abroad and seek to internalise aspects of other countries' innovation systems. There is a third option - that of firms seeking to modify the home-country innovation system which is expensive, and difficult to sustain in the long run.

Although the focus of this paper has been on home-country factors, it is important to emphasise the crucial nature of 'pull' factors. These have been noted here and elsewhere in the literature. In addition to proximity to markets and production units, firms also venture abroad to seek economies of agglomeration. In general, firms in industries with incomplete clusters will either evolve their technological specialisation towards a more complete industrial cluster, or they will relocate their activities to a geographic location where a more complete cluster exists. They can do so either by being passive and be acquired or merge with 
a firm with access to more complete clusters, or by relocating their locus by internationalisation. They have two other options, both of which are much less palatable, one of which is to die slowly, the other to re-orient their activity towards stronger domestic clusters. 


\section{References}

Archibugi, D. and Iammarino, S. (2000) Innovation and Globalisation: Evidence and Implications, in F. Chesnais, G. Ietto-Gillies and R. Simonetti (eds) European Integration and Global Corporate Strategies, Routledge, London

Archibugi, D. and Pianta, M. (1992) The Technological Specialization of Advanced Countries, Dodrecht, Kluwer Acedemic Publishers

Belderbos, R. (1999) Entry mode, organisational learning, and R\&D in foreign affiliates: Evidence from Japanese firms, mimeo, University of Maastricht

Belderbos, R. (2000) Overseas Innovations by Japanese Firms: An analysis of patent and subsidiary data, Research Policy, forthcoming

Bellak, C. and Cantwell, J. (1997) Small latecomer countries in a globalising environment: constraints and opportunities for catching-up, Development and International Cooperation, Vol 13, pp139-179

Benito, G. (2000) Industrial clusters and foreign companies' centres of excellence in Norway, in U. Holm and T. Pedersen (eds) The emergence and impact of MNC centres of excellence: a subsidiary perspective, Basingstoke: Macmillan, pp 97-112

Blanc, H. and Sierra C.(1999) the internationalisation of R\&D by multinationals: a trade-off between external and internal proximity, Cambridge Journal of Economics, Vol 23, 187-206

Cantwell, J (1987), 'The reorganisation of European industries after integration: selected evidence on the role of multinational enterprise activities', Journal of Common Market Studies, vol. 26, no. 2, ,pp. 127-151.

Cantwell J. (1989) Technological Innovation and Multinational Corporations, Oxford, Basil Blackwell

Cantwell, J. and Sanna Randaccio, F.(1990) The Growth of Multinationals and the Catching Up Effect, Economic Notes, Vol. 19, July, pp 1-23

Christiansen, M., Møller, J. and Smith, K. (1996) Innovation Policies for SMEs in Norway, Oslo, STEP report R-11

Davenport, S. and Bibby, S. (1999) Rethinking a National Innovation System: The Small Country as 'SME' Technology Analysis \& Strategic Management, Vol 11, pp 431-462

Dunning, J.H. and Narula, R. (1994) Transpacific direct investment and the investment development path: The record assessed, in Essays in International Business, No 10, May, pp1-64.

Dunning, J.H. and Narula, R. (1995) The R\&D activities of foreign firms in the United States. International Studies of Management \& Organization, 25 (1-2), 39-73.

Dunning, J.H. and Cantwell, J. (1991) MNEs, Technology and Competitiveness of European Industries, in European Economic Integration, G. Faulhaber and G. Tamburini (eds) , Boston, Kluwer Academic Publishers, pp 117-148

Etzkowitz, H. and Leydesdorff, L. (2000) The dynamics of innovation: from National Systems and "Mode 2" to a Triple Helix of university--industry--government relations, Research Policy (29)2, pp. 109-123

Florida, Richard (1997) The globalisation of R\&D: results of a survey of foreign-affiliated R\&D laboratories in the USA, Research Policy, Vol 26, pp 85-103 
Freeman. and B. Lundvall. (eds) (1988) Small Countries Facing the Technological Revolution, London, Pinter Publishers

Granstand, O. (1998) Towards a theory of the technology based firm, Research Policy, Vol 27, pp 465-490

Granstrand, L. Hakanson and S. Sjolander (eds) (1992) Technology Management and International Business, Internationalisation of R\&D and Technology. Chichester: John Wiley and Sons.

Granstrand, O., Patel, P. and Pavitt, K. (1997) "Multi-Technology Corporations: Why They Have "Distributed" Rather Than "Distinctive Core" Competencies", California Management Review, Vol. 39, No. 4: 8-25

Hagedoorn, J. and Schakenraad, J. (1994) the effect of strategic technology alliances on company performance, Strategic Management Journal, vol.15., pp. 291-311.

Hauknes, J. (1996) R\&D in Norway 1970-1993: an overview of the grand sectors, Step Report W2-96

Hodne, F. (1993) The multinational corporations of Norway, in G. Jones and G. Schröter (eds) The Rise of Multinationals in Continental Europe, Aldershot: Edward Elgar, pp 128-151

Hood, N. and Young, S. (1982) US Multinational R\&D: Corporate Strategies and Policy Implications for the UK, Multinational Business, Vol 2, pp 10-23.

Kuemmerle, W. (1996) Home Base and Foreign Direct Investment in R\&D, Unpublished PhD dissertation, Boston: HBS

Kuemmerle, W. (1997) Building effective R\&D capabilities abroad. 70.

Kuemmerle, W. (1999) The drivers of foreign direct investment into research and development: An empirical investigation. Journal of International Business Studies, 30 (1), 1-24.

Kvinge, T. and Narula, R. (2000) FDI in Norway's manufacturing sector, mimeo, University of Oslo

Lall, S. (1979) The International Allocation of Research Activity by U.S. Multinationals, Oxford Bulletin of Economics and Statistics, Vol 41, pp 313--331, 1979.

Mariani, M. (1999) Next to production or technological clusters? The economics of management of R\&D location, MERIT Research Memorandum 99-029

Narula, R. (1996) Multinational Investment and Economic Structure, Routledge, London

Narula, R. (1999a) Explaining Strategic R\&D alliances by European firms, Journal of Common Market Studies, Vol 37, no 4, 711-23

Narula, R. (1999b) Choosing between modes of non-internal technological activities by firms: some technological and economic factors, MERIT Research Memorandum 99-024

Narula, R. and Hagedoorn, J. (1999) Innovating through strategic alliances: moving towards international partnerships and contractual agreements, Technovation, Vol 19, pp 283-294

Nelson, R. and Rosenberg, N. (1993) Technical innovation and national systems, in Nelson, R. (ed) National Innovation Systems, Oxford: Oxford University Press, pp 3-28

NIFU (1999) Science and Technology Indicators, Oslo: NIFU

Niosi, J. (1999) The internationalisation of R\&D: from technology transfer to the learning organisation, Research Policy, Vol 28. pp 107-117 
Nygaard, Arne and Dahlstrom, Robert (1992), Multinational Company Strategy and Host Country Policy, Scandinavian Journal of Management, Vol 8, pp 3-13.

OECD (2000) Economic Survey of Norway, Paris: OECD

Ørstavik, F. and Nås, S. (1998) Institutional mapping of the Norwegian system of innovation, STEP report A-01

Patel, P. and Pavitt, K. (1998) national systems of innovation under strain: the internationalisation of corporate $\underline{\mathrm{R} \& \mathrm{D}}$, mimeo, SPRU

Patel, P. and Vega, M. (1999) Patterns of internationalisation and corporate technology: location versus home country advantages' Research Policy, Vol 28. pp

Pavitt, K. (1998) Technologies, products \& organisation in the innovating firm: What Adam Smith tells us and Joseph Schumpeter doesn't Industrial and Corporate Change, 7:433-452

Pearce, R and Singh, S. (1992) Globalising Research and Development, London: Macmillan

Pearce., R. and Papanastassiou, M. (1996) The Technological Competitiveness of Japanese Multinationals, AnnArbor: University of Michigan Press

Reve, T, Lensberg, T. And Gronhaug, K. (1992) Et Konkurransedyktig Norge, Oslo: Tano

Skoie, H. (1997) Norway - A Province of Science in a changing world, STS, report no 32

Stonehill, A. (1965) Foreign Ownership in Norwegian Industries, Oslo: Central Bureau of Statistics.

Teece, D. (1986) profiting from technological innovation: implications for integration, collaboration, licensing and public policy, Research Policy, Vol 15, pp 285-305

Walsh, V. (1988) Technology and Competitiveness of Small Countries: A Review, in C. Freeman. and B. Lundvall. (eds) Small Countries Facing the Technological Revolution, London, Pinter Publishers, pp $37-66$

Zander, I. (1999) How do you mean 'global'? An empirical investigation of innovation networks in the multinational corporation, Research Policy, Vol 28, pp 195-213

Zander, Ivo (1995) The Tortoise Evolution of the Multinational Corporation - Foreign Technological Activity in Swedish Multinational Firms 1890 - 1990, Stockholm: IIB.

Zanfei, A. (2000) Transnational firms and the changing organisation of innovative activities, Cambridge Journal of Economics, Vol 24, forthcoming 
Table 1: selected indicators, sample split into two Groups

\begin{tabular}{|c|c|c|c|c|c|c|c|}
\hline & & Size & \% of overseas & \% of employees & $\%$ of employees engaged & $\%$ of $R \& D$ employees & NFR subsidies as \\
\hline & Total employees worldwide & worldwide revenues $(\mathrm{MNOK})$ & sales & in $R \& D$ & in $R \& D$ outside Norway & outside Norway & $\%$ of $R \& D$ budget \\
\hline Group A & 52000 & 13385 & $59.4 \%$ & $3.2 \%$ & $0.2 \%$ & $5.0 \%$ & $3.0 \%$ \\
\hline Group B & 10300 & 1549 & $88.1 \%$ & $9.4 \%$ & $2.7 \%$ & $28.9 \%$ & $1.2 \%$ \\
\hline
\end{tabular}

\begin{tabular}{l|r}
\hline Table 2 R\&D expenditures of surveyed firms & $(\%)$ \\
million NOK & 34.6 \\
$<5$ & 23.1 \\
$5-9.99$ & 11.5 \\
$10-30$ & 23.1 \\
$30-50$ & 7.7 \\
$>50$ & 100 \\
\hline total & 26 \\
\hline n & 208 \\
mean & 5415 \\
\hline Sum & \\
\hline BERD in million NOK (1997) & 8600 \\
\hline share of BERD & $63 \%$ \\
\hline estimated share & \\
of total Norwegian & \\
\hline controlled R\&D & \\
\hline
\end{tabular}

Table 3: distribution of surveyed firms, number of firms and worldwide revenues

\begin{tabular}{l|rrrr}
\hline & \% offirms & \multicolumn{3}{c}{ \% of ww sales } \\
\hline & All firms & All firms & Group A & Group B \\
\hline Chemicals, pharmaceuticals and biotech & 26.9 & 5.8 & 3.6 & 33.3 \\
\hline mechanical equipment & 0.0 & 0.0 & 0 & 0 \\
\hline Metals and fabricated metals & 15.4 & 51.5 & 55.5 & 0 \\
\hline Other low tech sectors & 23.1 & 37.0 & 36.3 & 46.1 \\
\hline aerospace +transport eqpt & 3.8 & 0.7 & 0.8 & 0 \\
\hline control and measuring eqpt & 15.4 & 1.0 & 0 & 13.4 \\
\hline electronic, office and telecomms eqpt & 15.4 & 4.0 & 3.8 & 7.2 \\
\hline Total & 100 & 100.0 & 100.0 & 100.0 \\
\hline & & & & \\
\hline Low tech including metals & 38.5 & 88.5 & 91.8 & 46.1 \\
\hline electronics based sectors & 30.8 & 5.0 & 3.8 & 20.6 \\
\hline
\end{tabular}


Table 4: Extent of internationalisation of sales, production and $R \& D$

\begin{tabular}{|c|c|c|c|c|c|c|}
\hline & \multicolumn{3}{|c|}{ Group A } & \multicolumn{3}{|c|}{ Group B } \\
\hline & $\begin{array}{l}\% \text { of firms } \\
\text { with sales } \\
\text { in region }\end{array}$ & $\begin{array}{l}\% \text { of firms } \\
\text { with production } \\
\text { in region }\end{array}$ & $\begin{array}{l}\% \text { of firms } \\
\text { with } R \& D \\
\text { in region }\end{array}$ & $\begin{array}{l}\% \text { of firms } \\
\text { with sales } \\
\text { in region }\end{array}$ & $\begin{array}{l}\% \text { of firms } \\
\text { with production } \\
\text { in region }\end{array}$ & $\begin{array}{l}\% \text { of firms } \\
\text { with } R \& D \\
\text { in region }\end{array}$ \\
\hline $\mathrm{EU}$ & 90.9 & 72.7 & 27.3 & 100 & 64.3 & 42.9 \\
\hline North America & 54.5 & 45.5 & 9.1 & 100 & 64.3 & 42.9 \\
\hline Latin America & 72.7 & 45.5 & 0 & 85.7 & 7.1 & 0 \\
\hline Japan & 45.5 & 18.2 & 0 & 78.6 & 7.1 & 0 \\
\hline Other Asia & 92.9 & 35.7 & 9.1 & 92.9 & 35.7 & 14.3 \\
\hline Rest of World & 91.2 & 72.7 & 9.1 & 78.5 & 14.3 & 0 \\
\hline & Sales & Production & R\&D & Sales & Production & $\mathbf{R} \& \mathbf{D}$ \\
\hline $\begin{array}{l}\% \text { of firms with } \\
\text { 'global' presence [1] }\end{array}$ & 45.5 & 18.2 & 0 & 85.7 & 7.1 & 0 \\
\hline $\begin{array}{l}\% \text { of firms with } \\
\text { multinational presence [2] }\end{array}$ & 45.5 & 63.6 & 9.1 & 14.3 & 50 & 35.7 \\
\hline
\end{tabular}

[1] firms with presence in at least 5 of the 6 non-home regions

[2] firms with presence in 2 to 4 non-home regions

Table 5: 'how important are the following factors and considerations to your decision to maintain R\&D laboratories in Norway?"

\begin{tabular}{|c|c|c|c|c|}
\hline & \multicolumn{2}{|l|}{ GROUPA } & GROUP B & \\
\hline & mean & $\begin{array}{l}\text { \% of respondents } \\
\text { 'major or crucial } \\
\text { importance' }\end{array}$ & mean & $\begin{array}{l}\text { \% of respondents } \\
\text { 'major or crucial } \\
\text { importance' }\end{array}$ \\
\hline Availability of researchers & 4.6 & 91.6 & 4.3 & 85.7 \\
\hline Low cost of researchers & 2 & 8.3 & 2.5 & 21.4 \\
\hline Proximity of production units/customers & 3.6 & 66.6 & 2.5 & 28.6 \\
\hline presence of technical \& scientific Infrastructure & 3.4 & 50 & 3.6 & 57.1 \\
\hline access to raw materials \& other inputs & 2.3 & 33.3 & 1.4 & 7.1 \\
\hline monitoring the technology of competitors & 1.8 & 16.6 & 1.6 & 14.2 \\
\hline presence of important suppliers & 2.3 & 33.3 & 2.4 & 35.7 \\
\hline Demands/wishes of government & 1.9 & 26.7 & 1.1 & 0 \\
\hline
\end{tabular}

Table 6: Percentage of R\&D activity externally outsourced

\begin{tabular}{llrrr}
\hline & Average & $\mathbf{2 5 \%}$ or less & $\mathbf{2 6 - 5 0 \%}$ & $\mathbf{> 5 0 \%}$ \\
\hline Group A & 27.4 & 54.5 & 36.4 & 9.1 \\
& & & & \\
Group B & 18.2 & 78.6 & 21.4 & 0 \\
\hline
\end{tabular}

